\title{
Genetic diversity, population structure, and correlations between locally adapted zebu and taurine breeds in Brazil using SNP markers
}

\author{
Bárbara Machado Campos ${ }^{1,2}$ - Adriana Santana do Carmo ${ }^{3}$. Andrea Alves do Egito ${ }^{4}$. \\ Arthur Silva da Mariante ${ }^{4}$ Maria Socorro Muaés do Albuquerque ${ }^{5}$. \\ João José Simoni de Gouveia ${ }^{6}$ • Carlos Henrique Mendes Malhado ${ }^{7}$. \\ Lucas Lima Verardo ${ }^{8}$ - Marcos Vinícius Gualberto Barbosa da Silva ${ }^{8}$. \\ Paulo Luiz Souza Carneiro ${ }^{7}$
}

Received: 12 May 2017 / Accepted: 2 August 2017 /Published online: 15 August 2017

(C) Springer Science+Business Media B.V. 2017

\begin{abstract}
Genetic diversity is one of the most important issues in studies on conservation of cattle breeds and endangered species. The objective of this study was to estimate the levels of genetic differentiation between locally adapted taurine (Bos taurus taurus) and zebu (Bos taurus indicus) breeds in Brazil, which were genotyped for more than 777,000 SNPs. The fixation index $\left(F_{\mathrm{ST}}\right)$, principal component analysis (PCA), and Bayesian clustering were estimated. The $F_{\text {ST }}$ highlighted genetic differentiation between taurine and zebu breeds. The taurine lines, Caracu and Caracu Caldeano, had significant genetic differentiation $\left(F_{\mathrm{ST}}\right.$ close to $\left.5 \%\right)$
\end{abstract}

Bárbara Machado Campos

zoo.ufrb@yahoo.com.br

Adriana Santana do Carmo

adrianasantanacarmo@gmail.com

Andrea Alves do Egito

andrea.egito@embrapa.br

Arthur Silva da Mariante

arthur.mariante@embrapa.br

Maria Socorro Muaés do Albuquerque

socorro.maues@embrapa.br

João José Simoni de Gouveia

joao.gouveia@univasf.edu.br

Carlos Henrique Mendes Malhado

carlosmalhado@gmail.com

Lucas Lima Verardo

lucas_verardo@yahoo.com.br

Marcos Vinícius Gualberto Barbosa da Silva

marcos.vb.silva@embrapa.br despite their recent selection for different uses (meat and milk). This genetic variability can be used for conservation of locally adapted animals, as well as for breeding programs on zebu breeds. Introgression of zebu in locally adapted breeds was identified, especially in Curraleiro Pé-Duro breed. The Gyr breed, however, had low breed purity at genomic level due to its very heterogeneous mixing pattern.

Keywords Naturalized bovine - Conservation · Genomic . Introgression

Paulo Luiz Souza Carneiro

plscarneiro@gmail.com

1 Graduate Program of Animal Science, Universidade Estadual do Sudoeste da Bahia, 40 Praça Primavera, Bairro Primavera, Itapetinga, Bahia 457000-000, Brazil

2 Crescêncio Silveira Ave., Mercadão, Box 123, Vitória da Conquista, Bahia 45000-340, Brazil

3 Universidade Federal Goiás, Goiânia, Goiás 74690-900, Brazil

4 Brazilian Agricultural Research Corporation (Embrapa Genetic Resources and Biotechnology), Brasília, Distrito Federal 70770-901, Brazil

5 Brazilian Agricultural Research Corporation (Embrapa Beef Cattle), Campo Grande, Mato Grosso do Sul 79106-550, Brazil

6 Universidade Federal do Vale do São Francisco, Petrolina, Pernambuco 56300-000, Brazil

7 Universidade Estadual do Sudoeste da Bahia, Jequié, Bahia 45206-190, Brazil

8 Brazilian Agricultural Research Corporation (Embrapa Dairy Cattle), Juiz de Fora, Minas Gerais 36038-330, Brazil 


\section{Introduction}

Since the divergence of wild Aurochs (Bos primigenius), several types of cattle have accumulated distinct genetic variations, promoting highly differentiated phenotypes. It is estimated that the divergence that originated taurine and zebu cattle occurred long before domestication, between 8000 and 10,000 years ago. Taurine emerged in the Fertile Crescent while zebu cattle emerged in the Indus Valley, Pakistan (Ajmone-Marsan et al., 2010). After domestication, humanoriented selection added more complexity to the evolution of cattle species.

The first bovines arrived in Brazil between the sixteenth and seventeenth centuries, brought by Portuguese to be used as food and traction animals. After successive generations of random crossings, these animals adapted to the local environment and were recognized as locally adapted breed due to their ability to tolerate the high temperatures of the tropics and food shortages (McManus et al., 2009). In the midnineteenth century, trade routes between India and Brazil enabled the introduction of zebu cattle, and, as well as the locally adapted taurine breeds, they became naturalized in the country; however, the objective of zebu cattle was to increase the production of domestic herds (Silva et al., 2012).

The genetic variability of locally adapted breeds is mainly related to characteristics of adaptation and resistance to diseases (Bianchini et al., 2006; Nicolau et al., 2004). Thus, the maintenance of genetic diversity of each breed is important to meet the needs of production systems, in terms that it is not possible to assume which characteristics will be needed in the future. In addition, studies on genetic diversity are necessary to understand the available genetic resources and may aid in genetic breeding of animals under conservation (Boettcher et al., 2010).

Although there are studies that evaluated genetic diversity of cattle by pedigree and molecular markers (Porto-Neto et al., 2013; Santana et al., 2016), there is no study of the population genetic structure of large number of commercial and naturalized bovine breeds by single nucleotide polymorphism (SNP) markers. In this context, the objective of this study was to evaluate the genetic divergence between locally adapted breeds (Bos taurus taurus) and zebu breeds (Bos taurus indicus) using SNP markers.

\section{Material and methods}

Genotypes used in this study came from the DNA Bank which was undertaken by Embrapa Gado de Leite, Juiz de Fora, Brazil. All animals were genotyped using the Illumina Bovine HD Genotyping BeadChip, which includes 777,000 (HD; Illumina, San Diego, CA) by Neogen do Brasil Ltda. Autosomal genotypes were subjected to a quality control procedure, removing SNPs under the following criteria: call rate $<0.98$ and lower allele frequency $<0.02$. A total of 141 locally adapted taurine animals of Franqueiro $($ FRA $=41)$, Pantaneiro $($ PAN $=18)$, Curraleiro Pé-Duro $($ CUR $=17)$, Caracu $(C=24)$, and Caracu Caldeano $(\mathrm{CC}=41)$ breeds were compared with 553 zebu animals of Indubrasil ( $(\mathrm{ND}=38)$, Sindi ( $\mathrm{SI}=49)$, Tabapuã $(\mathrm{TAB}=24)$, and Gyr $(\mathrm{GI}=442)$ dairy breeds to assess the level of introgression among these populations. All genotyped animals are from a breeding program in Brazil, where Embrapa is responsible for genetic evaluations.

The global $F$ statistics $\left(F_{\mathrm{IT}}, F_{\mathrm{ST}}\right.$, and $\left.F_{\mathrm{IS}}\right)$ were calculated using the software GENEPOP 4.1.4 (Rousset, 2008). This software was also used to test the Hardy-Weinberg equilibrium deviations in loci at $5 \%$ probability. Within the genetic variability of the breed, the proportion of polymorphic loci $(\mathrm{PP})$ and the observed $\left(H_{\mathrm{O}}\right)$ and expected $\left(H_{\mathrm{E}}\right)$ heterozygosity was estimated using the software ARLEQUIN 3.5.2.2 (Excoffier and Lischer, 2010). The $F_{\mathrm{ST}}$, which measures the population differentiation (pair-to-pair), and the analysis of molecular variance (AMOVA) of breeds were calculated using the software ARLEQUIN 3.5.1.3 (Excoffier and Lischer, 2010) with $10^{3}$ bootstrap permutations.

The genetic structure of the population was inferred by applying a principal component analysis (PCA) for the data set of taurine and another for zebu breeds, using the software SMARTPCA (Patterson et al., 2006). Proportions of individual ancestry for $K$ (assumed number of ancestral populations) were calculated using software STRUCTURE (Pritchard et al., 2000). The ancestry patterns were generated using CLUMPP 1.1.2 (Jakobsson \& Rosenberg, 2007) and later visualized with DISTRUCT 1.1 (Rosenberg, 2004). For each value of $K$, ten independent chains were performed for each SNP set, each one consisting of burn-in of 1000 and 10,000 Monte Carlo iterations. These tests were performed for $K=1$ to $N$, in which $N$ is the total number of expected subpopulations +1 . The delta $K$ method (DK) was used to determine the number of subpopulations (Evanno et al., 2005).

\section{Results}

The evaluated populations had no significant Hardy-Weinberg equilibrium deviations. In all races/lines, the proportions of polymorphic loci (PP) were high and informative for the study of diversity. Genetic variability was identified for all breeds according to estimates of genetic diversity. A $F_{\text {IS }}$ greater than 0 was observed only in Sindi breed (Table 1).

The estimated global $F_{\mathrm{IT}}, F_{\mathrm{ST}}$, and $F_{\mathrm{IS}}$ were 0.1271 , 0.1363 , and -0.0106 , respectively. The observed $F_{\text {IT }}$ $(12.71 \%)$ revealed the presence of heterozygotes in the population, whereas the $F_{\text {IS }}$ (negative) indicated that there was no increase in inbreeding. $F_{\mathrm{ST}}$ pair-to-pair estimates ranged from 
Table 1 Genetic diversity of locally adapted taurine breeds/ lines and zebu breeds

\begin{tabular}{lllll}
\hline Breeds & PP & $H_{\mathrm{O}}{ }^{\mathrm{a}}$ & $H_{\mathrm{E}}{ }^{\mathrm{a}}$ & $F_{\mathrm{IS}}$ \\
\hline Caracu meat & 0.9545 & $0.33505 \pm 0.16732$ & $0.33445 \pm 0.15070$ & -0.00186 \\
Caracu Caldeano & 0.8872 & $0.32327 \pm 0.16910$ & $0.31771 \pm 0.15685$ & -0.01770 \\
Curraleiro Pé-Duro & 0.8868 & $0.33798 \pm 0.18498$ & $0.32582 \pm 0.15449$ & -0.03851 \\
Franqueiro & 0.9713 & $0.35563 \pm 0.16555$ & $0.34255 \pm 0.14793$ & -0.03869 \\
Pantaneiro & 0.9355 & $0.38232 \pm 0.18138$ & $0.35618 \pm 0.14486$ & -0.07570 \\
Gyr milk & 0.9936 & $0.36880 \pm 0.15847$ & $0.36660 \pm 0.15616$ & -0.00600 \\
Indubrasil & 0.9647 & $0.38415 \pm 0.16194$ & $0.37256 \pm 0.14297$ & -0.03155 \\
Sindi & 0.9726 & $0.37092 \pm 0.15017$ & $0.37551 \pm 0.13970$ & 0.01235 \\
Tabapuã & 0.9618 & $0.39108 \pm 0.16304$ & $0.38513 \pm 0.13756$ & -0.01580 \\
\hline
\end{tabular}

$P P$ proportion of polymorphic loci, $H_{\mathrm{O}}$ observed heterozygosity, $H_{\mathrm{E}}$ expected heterozygosity, $F_{\mathrm{IS}}$ coefficient of inbreeding

${ }^{\mathrm{a}}$ Mean \pm standard deviation
4.39 (Caracu and Caracu Caldeano) to 23.97\% (Indubrasil and Caracu Caldeano). Taurine breeds had different isolation levels, ranging from 7.88 (moderate) (Caracu x Franqueiro) and 7.97 (moderate) (Caracu $\times$ Pantaneiro) to $15 \%$ (high differentiation level) (Curraleiro Pé-Duro $\times$ Caracu Caldeano). On the other hand, results for zebu breeds were close to $5 \%$, indicating a low genetic differentiation and a probably greater gene flow between breeds (Table 2).

The variation within all breeds explained $85 \%$ of the total genetic variation. This result was confirmed by the $F_{\mathrm{ST}}(0.15)$ indicating a low gene flow between taurine and zebu breeds (Table 3 ). Among taurine, this variation was $89.56 \%$ with $F_{\text {ST }}$ of 0.10 , whereas in zebu animals, almost all variation is explained by differences within breeds $(94.66 \%)$, which is confirmed by the low $F_{\mathrm{ST}}$ (Table 3 ).

The first two components (PC1 and PC2) explained $(12.48 \%)$ the variation among breeds/lines locally adapted. The PC1 explained $6.95 \%$ of the variation and allowed to discriminate the Curraleira breed from the others, with some animals close to Pantaneira breed. PC2, which explained
$5.53 \%$ of the variation, discriminated the Franqueira breed of the Curraleira, Pantaneira, Caracu, and Caracu Caldeano. The Caracu lines were closer, presenting homogeneous genetic groups (Fig. 1a).

In the zebu, the first two components explained (6.36\%) of the variation (Fig. 1b). It was verified (PC1) that there was separation of the Gyr breed with the Sindi, Tabapuã, and Indubrasil breeds that are destined to the meat production. The second component (PC2) allows visualizing the proximity between Indubrasil, Sindi, and Tabapuã breeds.

Using STRUCTURE analysis, we observed the presence of two clusters, which differentiated the locally adapted taurine from zebu breeds, with $K=2$ (Fig. 2). Signs of introgression of zebu genes in taurine breeds were identified, except in Caracu Caldeano, originated from the selection of Caracu animals for dairy characteristics.

The genetic structure of taurine breeds indicated the presence of three clusters, with evident differentiation of Caracu Caldeano line from the other breeds (Fig. 3). Pantaneira breed has a greater diversity in its composition due to the proportion
Table 2 Estimates of genetic differentiation (pair-to-pair) between locally adapted taurine breeds/lines and zebu breeds. All $F_{\mathrm{ST}}$ estimates were significant $(p<0.05)$

\begin{tabular}{llllllllll}
\hline & C & CC & FRA & PAN & CUR & IND & TAB & SIN & GI \\
\hline C & & 0.0439 & 0.0788 & 0.0797 & 0.1203 & 0.1982 & 0.1882 & 0.1926 & 0.1849 \\
CC & 0.0439 & & 0.1126 & 0.1149 & 0.1500 & 0.2397 & 0.2351 & 0.2324 & 0.2130 \\
FRA & 0.0788 & 0.1126 & & 0.1010 & 0.1439 & 0.1719 & 0.1639 & 0.1685 & 0.1601 \\
PAN & 0.0797 & 0.1149 & 0.1010 & & 0.1330 & 0.1652 & 0.1542 & 0.1605 & 0.1552 \\
CUR & 0.1203 & 0.1500 & 0.1439 & 0.1330 & & 0.2132 & 0.2039 & 0.2059 & 0.1950 \\
IND & 0.1982 & 0.2397 & 0.1719 & 0.1652 & 0.2132 & & 0.0502 & 0.0634 & 0.0446 \\
TAB & 0.1882 & 0.2351 & 0.1639 & 0.1542 & 0.2039 & 0.0502 & & 0.0530 & 0.0505 \\
SIN & 0.1926 & 0.2324 & 0.1685 & 0.1605 & 0.2059 & 0.0634 & 0.0530 & & 0.0608 \\
GI & 0.1849 & 0.2130 & 0.1601 & 0.1552 & 0.1950 & 0.0446 & 0.0505 & 0.0608 & \\
\hline
\end{tabular}

C Caracu meat, FRA Franqueiro, IND Indubrasil, PAN Pantaneiro, CC Caracu Caldeano, GI Gyr milk, SIN Sindi, $T A B$ Tabapuã, $C U R$ Curraleiro Pé-Duro 
Table 3 Analysis of molecular variance (AMOVA) in the partitioning of genetic variation between and within locally adapted taurine breeds/lines and zebu breeds

\begin{tabular}{llllll}
\hline Structure & SV & DF & $\%$ Var & Fixation index & Nm \\
\hline Adapted taurine $\times$ zebu breeds & Between breeds & 1 & 15.00 & $F_{\mathrm{ST}}=0.1500^{* *}$ & 1.4116 \\
& Within breeds & 1386 & 85.00 & & \\
Locally adapted taurine breeds & Between breeds & 4 & 10.44 & $F_{\mathrm{ST}}=0.1044^{* *}$ & 2.1446 \\
& Within breeds & 277 & 89.56 & & \\
Zebu breeds & Between breeds & 3 & 5.34 & $F_{\mathrm{ST}}=0.0533^{* *}$ & 4.4400 \\
& Within breeds & 1102 & 94.66 & & \\
\hline
\end{tabular}

$S V$ source of variation, $D F$ degrees of freedom, \% Var proportion of total variance, $\mathrm{Nm}$ estimate of gene flow from the $F_{\mathrm{ST}} \mathrm{Nm}=\left(1-F_{\mathrm{ST}}\right) / 4 F_{\mathrm{ST}}$

*** Significant at $1 \%$ of probability of alleles of ancestral populations, whereas Curraleiro PéDuro and Franqueiro breeds have greater uniformity and low levels of introgression of other breeds. Delta $K$ analysis also allowed us to identify an additional peak in $K=5$ and observe the separation between the five taurine breeds/lines (Fig. 3).

Four clusters were estimated for zebu breeds, with additional peaks in $K=6$ and $K=7$ (Fig. 4). The Sindi breed had greater uniformity, while Indubrasil and Tabapuã showed similarities in their composition, with similar proportion of effect of other ancestral animals. Gyr breed had a high mixing level, which is consistent with the history of this breed (Fig. 4).

\section{Discussion}

Estimates for the observed heterozygosity $\left(H_{\mathrm{O}}\right)$ in all breeds indicate the presence of heterozygous animals in the population and consequently, greater allelic diversity, which may favor adaptation to changes in climate and productive practices. This heterozygosity is important for zebu breeds, which are raised under different production conditions in Brazil, as well as for locally adapted taurine breeds, which are also raised in different regions of the country and are important and viable targets for conservation. Regarding the taurine breeds, the results indicate that conservation strategies have allowed us to maintain diversity within populations, an unusual condition in animals under conservation, due to their small effective size and inbreeding crossings. Similar results were observed in locally adapted taurine breeds in Brazil using microsatellite markers (Egito et al., 2007) and in Cuban Creole cattle (Acosta et al., 2013).

The identified genetic variation partitioning the taurine breeds was similar to that reported by Líron et al. (2006), which observed $99 \%$ of variation within creole breeds of a

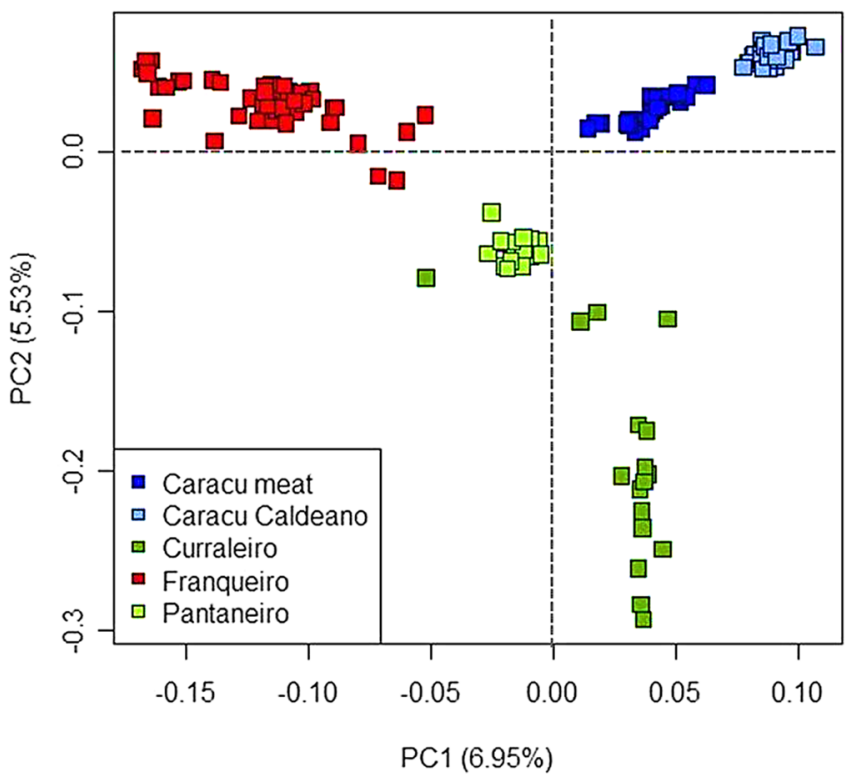

b

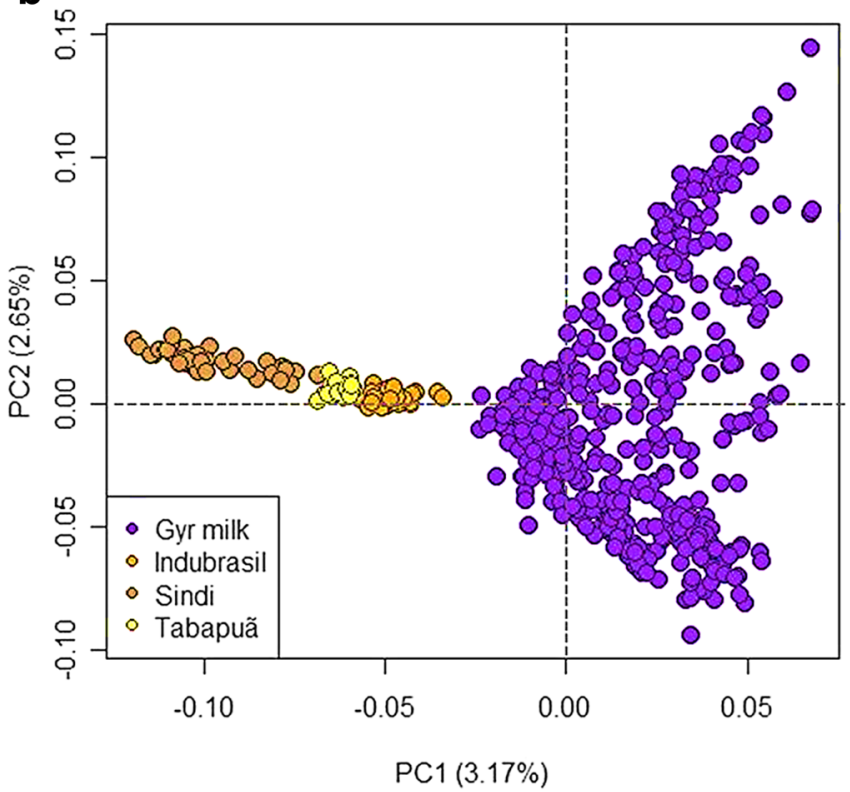

Fig. 1 Principal component analysis $(P C A)$ of locally adapted taurine breeds/lineages (a) and zebu breeds (b) 


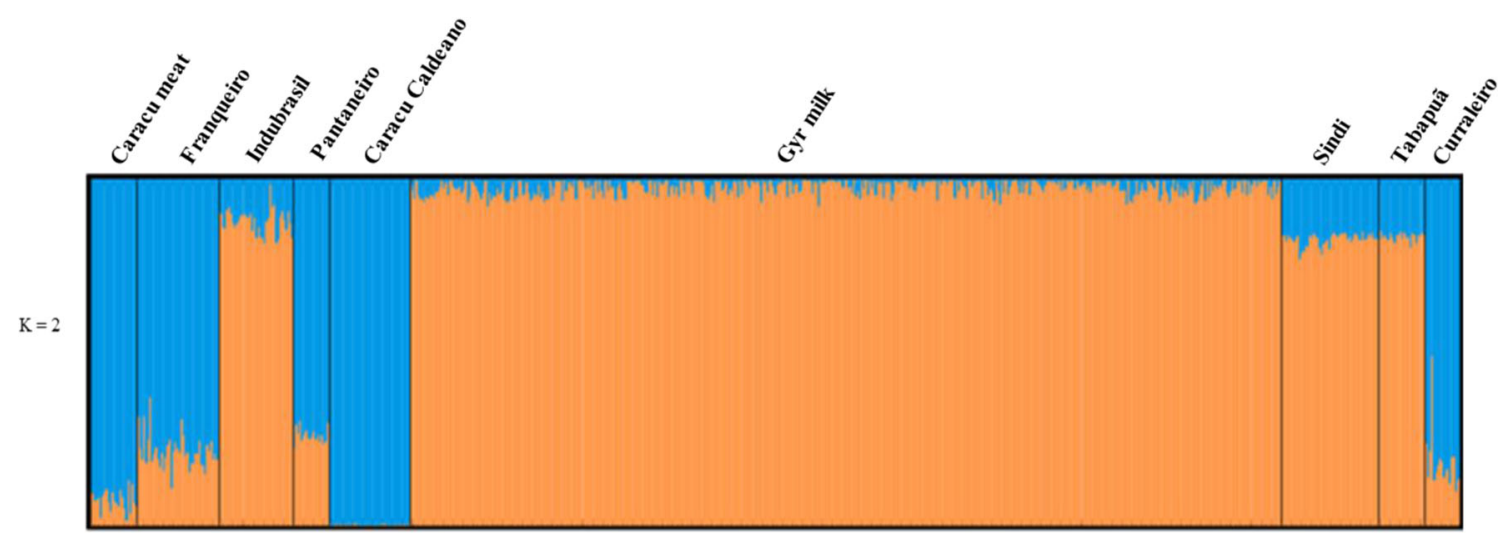

Fig. 2 Estimating the population structure obtained by STRUCTURE analyses for locally adapted taurine breeds/lines and zebu breeds. Each individual is represented by a thin vertical line, which is partitioned into colored segments that represent the proportional contribution of the inferred $K$ clusters. The populations are separated by thin vertical black lines

allow to reliably evaluate the diversity among the genetic groups. However, Gautier and Naves (2011) separated genetic groups with low percentages of explanation of the principal components, PC1 (8.1) and PC2 (5.91\%). The observed discrimination for the locally adapted breeds was similar to those reported by Villalobos-Cortés et al. (2010) in Creole cattle of Panama, which had $F_{\mathrm{ST}}$ of 0.10 and $\mathrm{Nm}$ lower than 1, indicating that a high $F_{\mathrm{ST}}$ and low levels of gene flow may determine the differentiation among populations.

The Gyr breed had greater dispersion and variability than Tabapuã, Indubrasil, and Sindi, possibly due to the type of selection (directed to milk production) and raising in this breed. Differently from taurine, zebu breeds showed less genetic differentiation $\left(F_{\mathrm{ST}}\right.$ close to $\left.5 \%\right)$, due to its greater gene flow between breeds, which

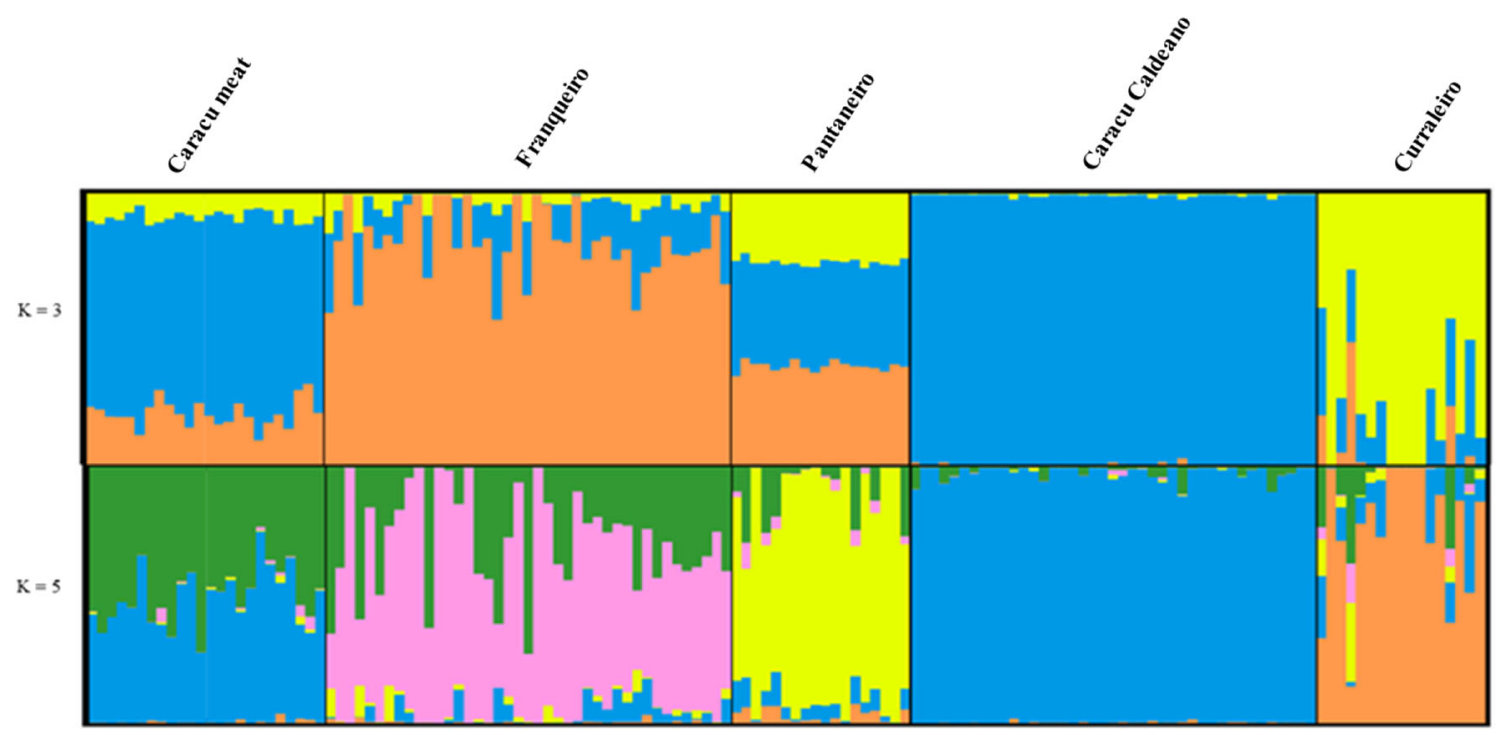

Fig. 3 Estimating the population structure obtained by STRUCTURE analyses for locally adapted taurine breeds/lines. Each individual is represented by a thin vertical line, which is partitioned into colored segments that represent the proportional contribution of the inferred $K$ clusters. The populations are separated by thin vertical black lines 


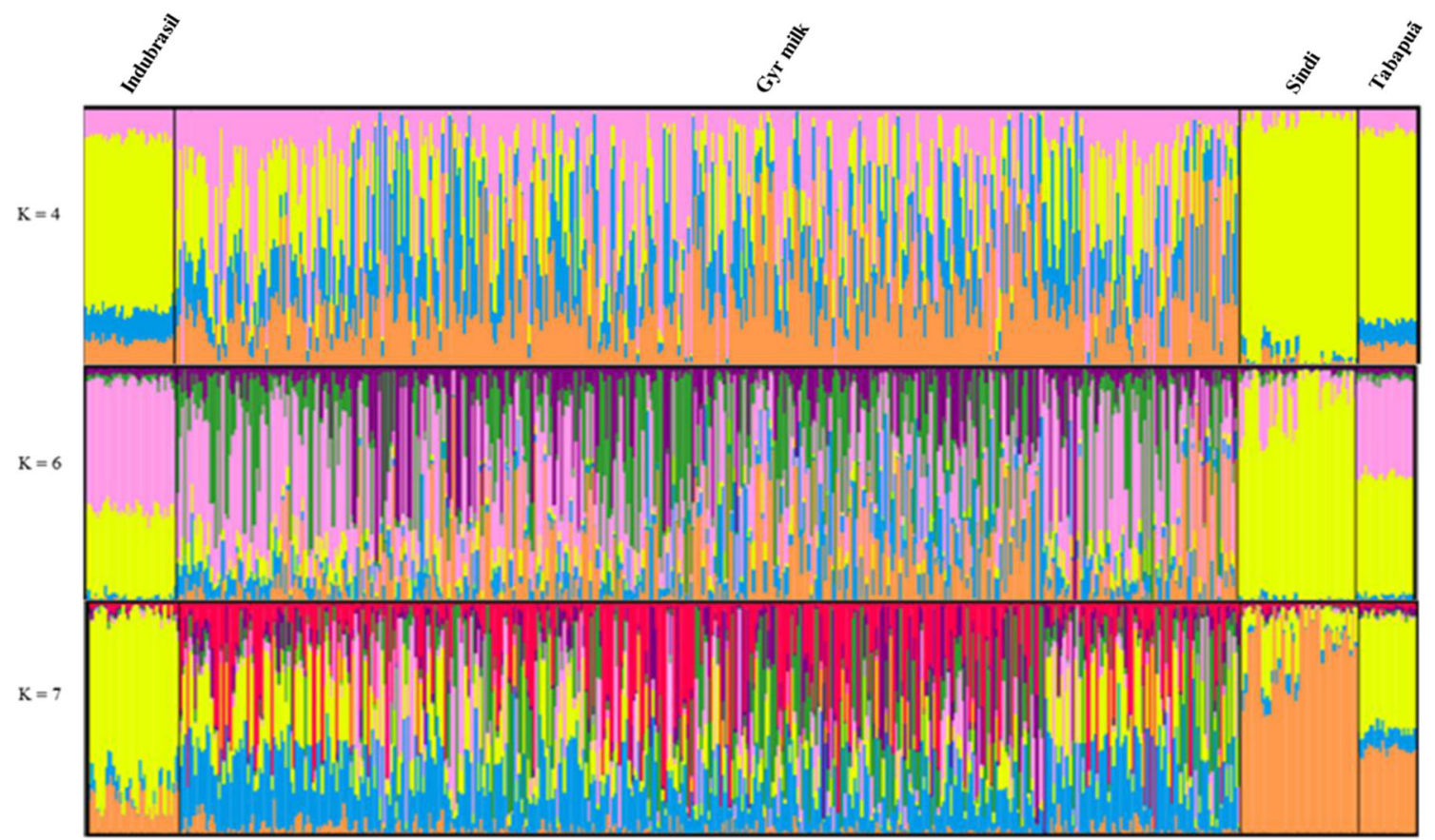

Fig. 4 Estimating the population structure obtained by STRUCTURE analyses for zebu breeds. Each individual is represented by a thin vertical line, which is partitioned into colored segments that represent the proportional contribution of the inferred $K$ clusters. The populations are separated by thin vertical black lines formed other breeds, such as Indubrasil, which has alleles from Nelore, Guzerá, and Gyr breeds (Vercesi Filho et al., 2002), and Tabapuã, which was formed from Nelore and Guzerá breeds (Oliveira et al., 2015). Studies on zebu breeds in the Americas (Villalobos-Cortés et al., 2015) and Sudan (Hussein et al., 2015) identified similar results for $F_{\mathrm{ST}}$ and Nm. Dani et al. (2008) observed estimates of $0.0840\left(F_{\mathrm{ST}}\right)$ and $2.7250(\mathrm{Nm})$ in Nelore cattle in Brazil.

The introgression of alleles observed between taurine and zebu breeds confirms that the introduction and use of zebu breeds in Brazil was responsible for the mixing in the genetic composition of these animals. Several crosses between zebu breeds and domestic cattle resulted in animals with breed purity masked by the mixture of taurine alleles (Mariante et al., 1999), indicating that locally adapted breeds served as a basis for zebu breeds formation, which formed the largest herds in the country (Euclides Filho, 2009; Primo, 1992). The presence of taurine alleles in Brazilian zebu breeds, such as Nelore and Gyr, was identified by O'Brien et al. (2015) and Egito et al. (2007) on locally adapted taurine and commercial zebu breeds in Brazil.

Caracu Caldeano line differed from the other breeds, probably due to its formation and objective of selection (milk yield) since 1893 (Queiroz et al., 2005). The homogeneity of the sample indicated the base effect as the main precursor of formation of these animals, which allowed us to identify the integrity of their genetic composition (Egito et al., 2014) and consequently, distinguish them from the other locally adapted breeds and commercial zebu breeds.

Proportion variations of ancestral populations in Franqueira, Pantaneira, and Curraleiro Pé-Duro breeds indicate that, although phenotypically characterized, these animals cannot be considered as breeds at genomic level. The Pantaneira breed showed uniform levels of mixture, which were attributed to its high estimates of genetic diversity. The history of this breed confirms the effect of Franqueiro and Curraleiro Pé-duro breeds in its formation (Mazza et al., 1992; Serrano et al., 2004).

A complex mixing pattern was observed in Gyr breed differing from the other zebu breeds that were more uniform. The genetic variability of Gyr breed can be explained by the formation of pure herds from 1993 with different purposes and selection intensities and subsequent crossings between animals from different herds (Gautier and Naves, 2011; Santana et al., 2014). Moreover, the absorption of characteristics from meat line (Standard Gyr) by Dairy Gyr may have generated more genetic variability (Leão et al., 2013; Reis Filho et al., 2010). Several studies on structure of populations showed reductions of effective population and increases in inbreeding among Gyr animals (Malhado et al., 2010; Faria et al., 2009).

Tabapuã breed had a mixing pattern, with contribution of other ancestor groups. This breed was developed in the early twentieth century from Creole population crosses, called Mocho Nacional, with zebu breeds, mainly Nellore. The 
similarity of proportion of ancestral contribution pattern of Tabapuã and Indubrasil breeds confirms the common crosses of Nelore and Guzerá cattle during their formation, which can be proven by their low index of genetic differentiation (Brasil et al., 2013; Vercesi Filho et al., 2002 and Oliveira et al., 2015). Sindi was the only breed probable presenting homogeneity in the population, as observed by the $F_{\text {IS }}$ statistic $(0.01235)$, indicating inbreeding among the animals due to the low Ne.

Genetic diversity estimates identified in locally adapted taurine breeds indicate good conservation prospects, while in zebu breeds, the existing variability can be exploited through selection. The presence of structuration in taurine breeds/lines denotes their adaptation to different environments, allowing us to consider them as distinct genetic resources. However, they showed a certain level of mixing with zebu breeds, especially the Curraleiro Pé-Duro breed. Caracu Caldeano line proved to be an extremely homogeneous population. The great gene flow among zebu breeds denotes their common origin and the crosses between these breeds imported from India. Although there is good phenotypic characterization of Gyr, this breed had a very pronounced mixing pattern, revealing little purity at genomic level.

Acknowledgements MVGBS was supported by Embrapa (Brazil) SEG 02.13.05.011.00.00 and CNPq 310199/2015-8 "Detecting signatures of selection from Next Generation Sequencing Data," CNPq PVE 407246/2013-4 "Genomic selection in dairy Gyr and Girolando breeds," MCTI/CNPq/INCT-Ciência Animal, and FAPEMIG CVZ PPM 00606/ 16 "Detecting signatures of selection in cattle from Next Generation Sequencing Data" appropriated projects. CHMM and PLSC are supported by CNPQ (Research Productivity Scholarship).

\section{Compliance with ethical standards}

Conflict of interest The authors declare that they have no competing interests.

\section{References}

Acosta, A. C., Uffo, O., Sanz, A., Ronda, R., Osta, E., Rodellar, C. et al., 2013. Genetic diversity and differentiation of five Cuban cattle breeds using 30 microsatellite loci, Journal of Animal Breeding and Genetics, 130, 79-86.

Ajmone-Marsan, P., Garcia, J. F., Lenstra, J. A., Consortium, T. G., 2010. On the origin of cattle: how Aurochs became cattle and colonized the word, Evolutionary Anthropology, 19,148-157.

Bianchini, E., McManus, C., Lucci, C. M., Fernandes, M. C. B., Prescott, E., Mariante, A. S., Egito, A. A. 2006. Características corporais associadas com a adaptação ao calor em bovinos naturalizados brasileiros, Pesquisa Agropecuária Brasileira, 41, 9, 1443-1448.

Boettcher, P. J., Tixier-Boichard, M., Toro, M. A., Simianer, H., Eding, H., Gandini, G. et al., 2010. Objectives, criteria and methods for using molecular genetic data in priority setting for conservation of animal genetic resources, Animal Genetics, 41, 64-77.

Brasil, B. S. A. F., Coelho, E. G. A., Drummond, M. G., Oliveira, D. A. A., 2013. Genetic diversity and differentiation of exotic and
American commercial cattle breeds raised in Brazil, Genetics and Molecular Research, 12, 4, 5516-5526.

Dani, M. A. C., Heinneman, M. B., Dani, S. U., 2008. Brazilian Nelore cattle: a melting pot unfolded by molecular genetics, Genetics and Molecular Research, 7, 4, 1127-1137.

Egito, A. A., Lara, M. A. C., Albuquerque, M. S. M., Martinez, A. M., Lando, V., Juliano, R. S. et al., 2014. Estrutura populacional e diversidade genética de raças bovinas brasileiras localmente adaptadas, Actas Ibero Americanas de Conservación Animal, 4, $16-18$.

Egito, A. A., Paiva, S. R., Albuquerque, M. S. M., Mariante, A. S., Almeida, L. D., Castro, S. R., Grattapaglia, D., 2007. Microsatellite based genetic diversity and relationships among tem creole and commercial cattle breeds raised in Brasil. BMC Genetics, $8,83,1471-2156$.

Euclides Filho, K., 2009. Evolução do melhoramento genético de bovinos de corte no Brasil, Revista Ceres, 56, 5, 620-626.

Evanno, G., Regnaut, S., Goudet, J., 2005. Detecting the number of clusters of individuals using the software structure: a simulation study, Molecular Ecology, 14, 8, 2247-2620.

Excoffier, L., Lischer, H. E. L., 2010. Arlequin suite ver 3.5: a new series of programs to perform population genetics analyses under Linux and Windows, Molecular Ecology Resources, 10, 564-567.

Faria, F. J. C., Filho, A. E. V., Madalena, F. E., Josahkian, L. A., 2009. Pedigree analysis in the Brazilian Zebu breeds, Journal Animal Breedins and Genetics, 126, 148-153.

Gautier, M., Naves, M., 2011. Footprintis of selection in the ancestral admixture of a new world creole cattle breed, Molecular Ecology, 20, 3128-3143.

Hussein, I. H., Alam, S. S., Makkwi, A.A.A., Sid-Ahmed S. E., Abdoon, A., Hassanane, M., 2015. Genetic diversity between and within Sudanese zebu cattle breeds using microsatellite markers, Research in Genetics, 10, 1-16.

Issa, E. C., Jorge, W., Egito, A. A., Sereno, J. R. B., 2009. Cytogenetic analysis of the y chromosome of native Brazilian bovine breeds: preliminary data. Archivos de Zootecnia, 58, 221, 93-101.

Jakobsson, M., Rosenberg, N. A., 2007. CLUMPP: a cluster matching and permutation program for dealing with label switching and multimodality in analysis of population structure, Bioinformatics, 23, 14, 1801-1806.

Leão, G. F. M., Pivatto, D. R. D., Carniel, H., Rodrigues, M. G. K., Braga, R. A., Silva, M. R. H., Teixeira, P. P. M., 2013. Melhoramento genético em zebuínos leiteiros-uma revisão, ACSAAgropecuária Científica no Semiárido, 9, 4, 09-14.

Lirón, J. P., Bravi, C. M., Mirol, P. M., Peral-García, P., Giovambattista, G., 2006. African matri lineages in American Creole cattle: evidence of two independent continental sources, Animal Genetics, 37, 379382.

Malhado, C. H. M., Carneiro, P. L. S., Malhado, A. C. M., Martins, J. A. M., Martins Filho, R., Bozzi, R., 2010. History of registered Gyr breed in Brazilian Northeast: population structure and genetic improvement of growth traits, Ciência Rural, 40, 6, 1385-1391.

Mariante, A.S., Albuquerque, M.S. M., Egito, A. A., McManus, C., 1999. Advances in the Brazilian animal genetic resources conservation programme, AGRI, 25, 109-123.

Mazza, M. C. M., Mazza, C. A., Sereno, J. R. B., Santos, S. A. L., Mariante, A. S., 1992. Conservation of pantaneiro cattle in Brazil historical origin, Zootecnia, 41, 154, 443.

McManus, C., Prescott, E., Palulo, G. R., Bianchini, E., Louvandini, H., Mariantes, A. S., 2009. Heat tolerance in naturalized Brasilian cattle breeds, Livestock Science, 120, 256-264.

Nicolau, C. V. J., Silva, R. G., Mota, L. S. L. S., Veríssimo, C. J., 2004. Características da pele e do pelame em bovinos da raça Caracu, Archivos de Zootecnia, 53, 25-34.

O’Brien, A. M. P., Holler, D., Boison, S. A., Milanesi, M., Bomba, L., Utsunomiya, Y., 2015. Low levels of taurine introgression in the 
current Brazilian Nelore and Gir indicine cattle populations, Genetics Selection Evolution, 47, 31.

Oliveira, A. P., Malhado, C. H. M., Barbosa, L. T., Martins Filho, R., Carneiro, P. L. S., 2015. Inferência bayesiana na avaliação genética de bovinos da raça tabapuã do nordeste brasileiro, Revista Caatinga, 28, 4, 227-234.

Patterson, N., Prince, A. L., Reich, D., 2006. Population structure and eige analysis, PLoSGenetics, 2, 12, 190.

Porto-Neto, L.R., Sonstegard, T.S., Liu, G.E., Bickhart, D.M., Silva, M.V., Machado, M.A. et al., 2013. Genomic divergence of zebu and taurine cattle identified through high-density SNP genotyping, BMC Genomics, 14:876.

Primo, A. T., 1992. El ganado bovino ibérico em las américas: 500 anos después, Zootecnia, 41, 54, 421-432.

Pritchard, J. K., Stephens, M., Donnelly, P., 2000. Inference of population structure using multilocus genotype data, Genetics, 155, 945-959.

Queiroz, S. A., Pelicioni, L. C., Silva, B. F., Sesana, J. C., Martins, M. I. E. G., Sanches, A., 2005. Índices de Seleção para um Rebanho Caracu de Duplo Propósito, Revista Brasileira de Zootecnia, 34, 3 , 827-837.

Reis Filho, J. C., Lopes, P. S., Verneque, R. S., Torres, R. A., Teodoro, R. L., Carneiro, P. L. S., 2010. Population structure of Brazilian Gyr dairy cattle, Revista Brasileira de Zootecnia, 39, 12, 2640-2645.

Rosenberg, N. A., 2004. DISTRUCT: a program for the graphical display of population structure, Molecular Ecology, 4, 137-138.

Rousset, F., 2008. GENEPOP'007: a complete re-implementation of the genepop software for Windows and Linux, Molecular Ecology Resources, 8, 1, 103-106.
Santana Jr, M. L., Pereira, R. J., Bignardi, A. B., El Faro, L., Tonhati, H., Albuquerque, L. G., 2014. History, structure, and genetic diversity of Brazilian Gir cattle, Livestock Science, 163, 26-33.

Santana Jr, M.L., Pereira, R.J., Bignardi, A.B., Ayres, D.R., Menezes, G.R.O., Silva, L.O.C. et al., 2016. Structure and genetic diversity of Brazilian Zebu cattle breeds assessed by pedigree analysis, Livestock Science, 187, 6-15.

Serrano, G. M., Egito, A. A., McManus, C., Mariante, A. S., 2004. Genetic diversity and population structure of Brazilian native bovine breeds, Pesquisa Agropecuária Brasileira, 39, 6, 543-549.

Silva, M. C., Boaventura, V. M., Fioravanti, M. C. S., 2012. História do Povoamento Bovino no Brasil Central, Revista UFG, 13, 34- 41.

Toro, M. A., Caballero, A., 2005. Characterization and conservation of genetic diversity in subdivided populations, Philosophical Transactions of the Royal Society B, 360, 1367-1378.

Vercesi Filho, A. E., Carvalho, F. F. J., Madalena, F. E., Josahkian, L. A., 2002. Estrutura populacional do rebanho Indubrasil registrado no Brasil, Archivos Latinoamericanos de Producción Animal, 10, 2, 86-92.

Villalobos-Cortés, A., Martínez, A., Veja-Pla, J. L., Landi, V., Queiroz, J., Marques, J. R., et al., 2015. Genetic relationships among five zebu breeds naturalized in America accessed with molecular markers, Italian Journal of Animal Science, 14, 158-162.

Villalobos-Cortés, A. I., Martínez, A. M., Escobar, C., Veja-Pla, J. L., Delgado, J. V., 2010. Study of genetic diversity of the Guaymi and Guabala bovine populations by means of microsatellites, Livestock Science, 131, 45-51. 